\title{
PENENTUAN SEBAB KEMATIAN DALAM VISUM ET REPERTUM PADA KASUS KARDIOVASKULER
}

\author{
Taufik Suryadi ${ }^{1}$ \\ ${ }^{1}$ Bagian Imu Kedokteran Forensik dan Medikolegal Fakultas Kedokteran Universitas Syiah Kuala \\ Corresponding Author: abiforensa@yahoo.com
}

\begin{abstract}
Abstrak
Penyakit kardiovaskuler merupakan penyakit yang paling banyak menyebabkan kematian mendadak. Dari sudut pandang patologi forensik sangat penting ditentukan penyebab kematian apakah kematian wajar atau tidak wajar sehingga dilakukan pemeriksaan forensik guna penerbitan visum et repertum. Pada beberapa kesimpulan visum et repertum disebutkan bahwa dengan hanya pemeriksaan luar postmortem maka penyebab kematian mendadak kardiovaskuler tidak dapat ditentukan karena tidak dilakukan pemeriksaan dalam (autopsi). Penyebab kematian berdasarkan pemeriksaan luar postmortem pada kasus kematian mendadak kardiovaskuler dapat ditentukan dengan langkah-langkah yang harus dilakukan untuk kondisi tersebut dengan mengumpulkan data-data personal dasar, kesaksian, wawancara dengan keluarga, riwayat medik, riwayat pengobatan dan hal-hal yang berhubungan dengan kematian serta melihat tanda-tanda klinis spesifik setelah kematian. Penentuan sebab kematian dengan pemeriksaan luar postmortem ini disebut sebab kematian klinis dengan mengenali kondisi klinis sebelum pasien meninggal dunia. Apabila dilakukan autopsi baik klinis maupun forensik maka dapat dikatakan sebagai sebab kematian epidemiologis dan jika ditambahkan pemeriksaan penunjang berupa pemeriksaan histologi, patologi, toksikologi, biokimia dan biomolekuler maka disebut sebab kematian kausalitas. Dari sudut pembuktian medikolegal masing-masing sebab kematian mempunyai kasta yang berbeda yang tentu saja pemeriksaan lengkap mulai dari pemeriksaan luar postmortem, autopsi dan pemeriksaan penunjang berada pada kasta tertinggi.
\end{abstract}

Kata kunci: kematian-mendadak-kardiovaskuler, sebab-kematian, visum-et-repertum 


\title{
Determination of Cause of Death in Visum et Repertum in the Cardiovascular Case
}

\begin{abstract}
Cardiovascular disease is the most likely to cause sudden death. From the viewpoint of the forensic pathology it is very important to determine the cause of death whether the death is natural or unnatural so that a forensic examination is carried out to publish the visum et repertum. In several visum et repertum conclusions, the postmortem report stated that with only a postmortem external examination, the cause of sudden cardiovascular death cannot be determined because there is no internal examination (autopsy). The cause of death based on postmortem external examination in cases of sudden cardiovascular death can be determined by steps to be taken for the condition by collecting basic personal data, testimony, interviews with family, medical history, pharmaceutical history and matters related to death and see specific clinical signs after death. This determination of the cause of death by postmortem external examination is called the cause of clinical death by recognizing the clinical condition before the patient dies. If an autopsy is done both clinically and forensically it can be said to be the cause of epidemiological death and if added investigations in the form of histological, pathological, toxicological, biochemical and molecular biology examinations are called causes of causality deaths. From the point of view of medico-legal evidence, each cause of death has a different caste, of course, complete examinations starting from postmortem exams, autopsies and investigations are in the highest caste.
\end{abstract}

Key words: death-cause-sudden-cardiovascular, death-visum-et-repertum 


\section{PENDAHULUAN}

Kematian adalah berhentinya fungsi biologis yang mempertahankan kehidupan seseorang. Pada dasarnya kematian disebabkan oleh gagalnya fungsi salah satu dari tiga pilar kehidupan manusia yaitu gagalnya fungsi otak (central nervous system) yang ditandai dengan keadaan koma, gagalnya fungsi jantung (circulatory system) dengan gejala sinkop, dan gagalnya fungsi paru-paru (respiratory system) yang menyebabkan asfiksia. ${ }^{1,2,3}$ Kematian dapat terjadi perlahan-lahan mengikuti perjalanan penyakit, namun juga dapat terjadi secara mendadak. Pemeriksaan kematian mendadak sering dilakukan oleh dokter ahli forensik mengingat pada kasus kematian mendadak dapat timbul kecurigaan apakah ada unsur-unsur tindak pidana sehingga harus diperlakukan sebagai kematian yang tidak wajar (unnatural) sebelum dapat dibuktikan bahwa kematian tersebut bersifat wajar (natural) secara ilmiah. ${ }^{4}$ Kematian mendadak sering disamakan dengan kematian wajar yang tidak terduga (sudden natural unexpected death), yaitu suatu kematian yang disebabkan oleh karena penyakit alamiah bukan akibat trauma atau keracunan. ${ }^{5}$

Dari sudut pandang patologi forensik sangat penting ditentukan cara kematian yaitu wajar (natural) atau tidak wajar (unnatural). Kematian wajar diartikan sebagai kematian akibat penyakit ataupun proses penuaan. Sementara kematian tidak wajar maksudnya kematian akibat pembunuhan (kriminal), bunuh diri atau kecelakaan. ${ }^{6}$ Pada kasus-kasus kematian forensik diperlukan adanya suatu pembuktian mengenai cara kematian (manner of death), sebab kematian (cause of death) dan mekanisme kematian (mechanism of death) seseorang yang akan dituangkan pada visum et repertum (VeR). Diperlukan suatu pemahaman bagaimana mekanisme dan sebabsebab kematian yang mungkin saja terjadi dan bagaimana tanda-tanda yang terlihat dari setiap sebab dan mekanisme kematian yang diperoleh pada tubuh korban.

Dalam literatur disebutkan bahwa penyebab kematian sebagai akibat dari koma, asfiksia dan sinkop. ${ }^{1}$ Ketiga penyebab kematian ini tentunya dalam tataran patofisiologis atau bisa dikatakan mekanisme kematian bukan penyebab kematian. Namun dalam hal pelaporan visum et repertum ketiga penyebab kematian tersebut harus dijelaskan secara temuan postmortem. Pada saat membuat kesimpulan visum et repertum, dokter harus memberikan laporan objektif yang ditemukan pada jenazah. Apa yang terjadi pada tubuh jenazah itulah yang dibuat sebagai penyebab kematian yang dapat dilihat pada pemeriksaan luar dan dalam (autopsi) pada jenazah.

Kematian mendadak secara umum dapat disebabkan berbagai kelainan sistem tubuh diantaranya sistem kardiovaskular, respirasi, saraf pusat, gastrointestinal, urogenital, endokrin- 
metabolik dan hemopoetik. Di seluruh dunia, penyakit kardiovaskuler menempati urutan teratas sebagai penyakit yang menyebabkan kematian secara umum diikuti dengan penyakit infeksi dan kanker. ${ }^{7}$ Khusus kematian mendadak kelainan sistem kardiovaskuler juga menempati urutan pertama sebagai penyebab utama (berkisar $60 \%$ kasus). ${ }^{5,8}$

Penyebab kelainan kardiovaskuler bermacam-macam, antara lain kelainan pembuluh koroner, infark miokard, miokarditis, kardiomiopati, kelainan katup jantung, dan akibat kelainan genetik. Sekitar $80 \%$ kematian kardiovaskuler berhubungan dengan atheroslerosis koroner., ${ }^{6,7}$ Kecurigaan kasus kematian mendadak kardiovaskuler sering menimbulkan pertanyaan, sehingga sangat perlu diperhatikan beberapa hal tentang umur, jenis kelamin, pekerjaan, gaya hidup dan aktivitas sebelum kematian., 4

\section{PENENTUAN SEBAB KEMATIAN}

Proses kematian biasanya disebabkan oleh trauma (rudapaksa), asfiksia karena berbagai macam penyebab asfiksia seperti asfiksia mekanik dan keracunan serta penyakit misalnya penyakit sistemik, degeneratif, kanker dan infeksi. ${ }^{5,6}$ Pada kematian mendadak kardiovaskuler penyebab kematiannya adalah penyakit atau kelainan kardiovaskuler itu sendiri. Dalam literatur menyebutkan ada beberapa metode penentuan sebab kematian diantaranya melalui pemeriksaan eksternal postmortem (sehari-hari disebut pemeriksaan luar), pemeriksaan internal (autopsi/ pemeriksaan dalam) dan pemeriksaan penunjang.

Ilmu kedokteran telah membuat klasifikasi penyebab kematian ke dalam empat tipe berdasarkan jenis penyakit/patologi yang berhubungan dengan efek yang ditimbulkan pada berbagai organ. Tipe penyebab kematian merupakan suatu jembatan tanatologis yang menghubungkan antara penyakit dan penyebab kematian yaitu kemartian tipe linear, tipe divergen, tipe konvergen dan tipe kompleks. ${ }^{9}$ Pada kematian tipe linear, terdapat hubungan langsung antara penyebab kematian dengan penyakit dasarnya dengan kata lain bahwa penyebab kematian seseorang dapat ditentukan dengan melihat kelainan organ tertentu yang mendasari misalnya pada seseorang dengan riwayat penyakit jantung koroner (PJK), terdapat suatu keadaan penebalan dan penyumbatan arteri koronaria sehingga menyebabkan infark miokard dan lebih lanjut lagi menimbulkan kematian oleh karena timbul keadaan komplikasi temponade perikardium. $^{9}$ 
Pada kematian tipe divergen, tidak terdapat hubungan langsung antara penyebab kematian dengan penyakit dasarnya dengan kata lain seseorang yang memiliki penyakit kronis yang berat pada suatu organ. Kematian yang ditimbulkan bukanlah secara langsung oleh karena penyakit pada suatu organ tersebut tetapi karena berbagai komplikasi non-organ yang ditimbulkan, contohnya seseorang yang mengalami keganasan akan timbul gejala sindrom lisis tumor, kakheksia, anemia, intoksikasi sehingga pada akhirnya meninggal oleh karena komplikasi nonorgan tersebut. ${ }^{9}$

Kematian tipe konvergen merupakan tipe kematian yang disebabkan berbagai keadaan patologi pada organ tubuh akan menyebabkan kerusakan pada satu organ vital sehingga menyebabkan kematian pada seseorang. Dengan kata lain, penyakit yang mendasari di berbagai sistem organ menyebabkan kematian melalui fase patogen akhir yang umum bagi penyakit yang mendasari tersebut, contohnya pada seseorang dengan riwayat stenosing coronary sclerosis, ulkus gaster kronik yang disertai perdarahan berulang dan emfisema yang disertai dengan bronkitis kronik meninggal oleh karena komplikasi berbagai keadaan tersebut menimbulkan keadaan acute coronary insufisiensi. ${ }^{9,10}$

Pada kematian tipe kompleks, kematian timbul oleh karena kelainan/penyakit pada berbagai organ yang masing-masingnya menimbulkan berbagai komplikasi yang saling dapat menimbulkan kematian antara satu dan lainnya, misalnya seseorang akan dapat meninggal oleh karena hipertensi yang disertai stenosis arteri basilaris dan emfisema yang disertai bronkitis kronis. Keadan tersebut masing-masingnya akan menimbulkan komplikasi berupa ensefalomalasia dan bronkial pneumonia yang masig-masingnya memiliki peran untuk saling menyebabkan kematian pada seseorang. ${ }^{9,10}$ Secara skematis penentuan tipe kematian menurut kedokteran terangkum dalam bagan 1 . 


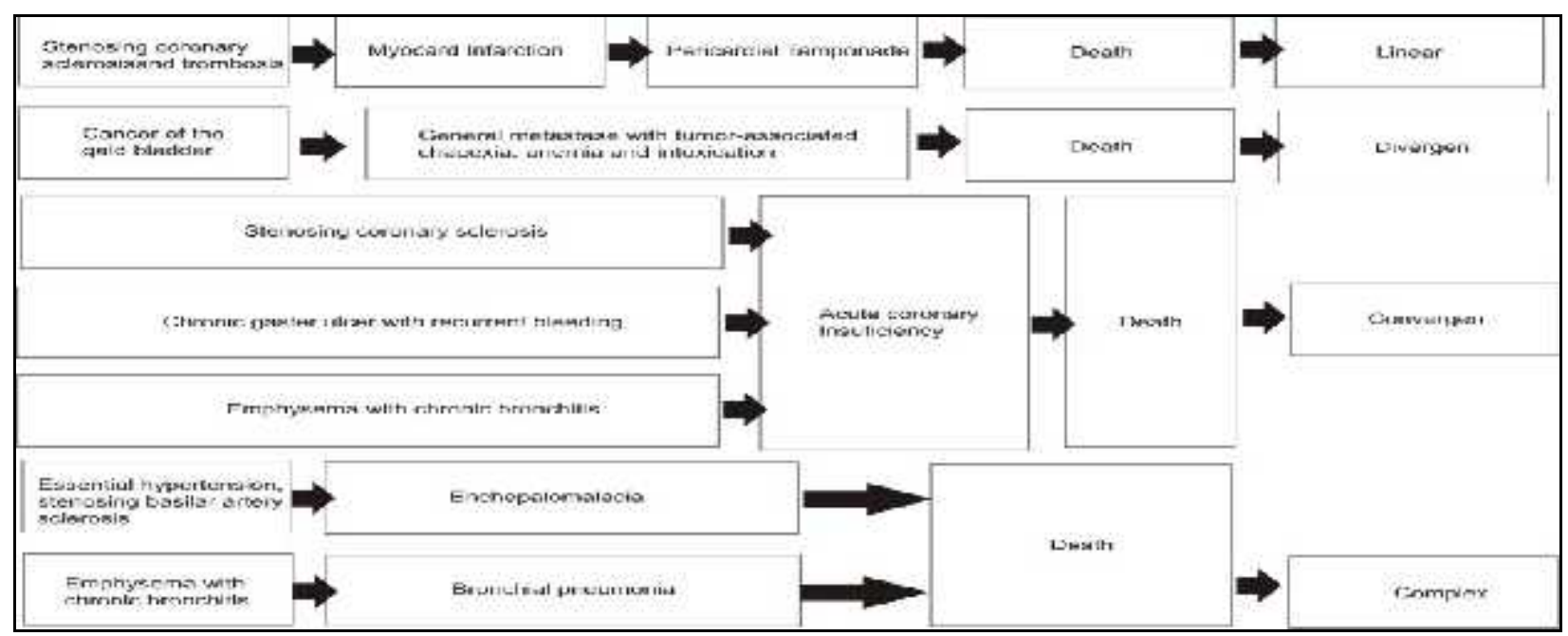

Bagan.1. Tipe-tipe penyebab kematian ${ }^{9}$

\section{HISTORIA MEDIS}

Sebagai salah satu sumber data dalam menentukan tipe penyebab kematian, historia medis yang tertulis dalam rekam medik pasien menjadi sangat penting sebagai sumber informasi riwayat penyakit yang diderita pasien sebelum meninggal dunia. Rekam medik merupakan kumpulan data penting terkait kondisi kesehatan dan riwayat hidup pasien. Rekam medik berisi data tentang penyakit yang diderita pasien dimasa lampau maupun saat ini dan ditulis langsung oleh tenaga kesehatan profesional yang merawat pasien. Salah satu manfaat rekam medik ialah untuk kepentingan penelitian spesifik terkait penyakit dan terapi yang pernah dialami pasien. Rekam medik juga berisi keterangan kematian untuk pasien yang meninggal saat menjalani perawatan, namun tidak untuk pasien death on arrival (DOA). Keterangan kematian dalam rekam medik terdiri dari nama lengkap pasien, umur dan jenis kelamin, alamat, nama petugas kesehatan yang merawat, dan penyebab kematian dalam bentuk sertifikat kematian yang dibuat oleh dokter ahli yang bertanggung jawab terhadap pasien tersebut. ${ }^{11}$

Langkah-langkah penentuan sebab kematian berdasarkan historia morbi yaitu dengan mengumpulkan data-data yang berhubungan dengan keadaan klinis pasien/korban: ${ }^{6}$ (a) Data personal dasar: meliputi umur, jenis kelamin, pekerjaan, gaya hidup, aktivitas sehari-hari, (b) Hal-hal yang berhubungan dengan kematian: tanggal, interval waktu, tempat kematian, ada saksi atau tidak, (c) Riwayat medik: status kesehatan umum, penyakit serius sebelumnya seperti sinkop, nyeri dada, palpitasi, infark miokard, hipertensi, infeksi saluran nafas, epilepsi, asma, (d) Komsumsi obat-obatan kardiovaskuler, (e) Riwayat keluarga: penyakit jantung iskemik, 
kematian mendadak, aritmia, dan (f) Test jantung sebelumnya seperti elektrocardiogram pada saat resusitasi, pengukuran enzim jantung dan troponin.

\section{PEMERIKSAAN LUAR POSTMORTEM}

Kualitas hasil pemeriksaan luar postmortem banyak dikritisi beberapa dekade terakhir. Persoalan yang timbul tentang penentuan sebab kematian berdasarkan pemeriksaan luar postmortem, apakah hanya dengan pemeriksaan luar postmortem dapat menentukan penyebab kematian?, bagaimana validitasnya?, bagaimana aspek medikolegalnya? Titik utama kritik terletak pada aspek hukum yaitu tidak tepatnya penentuan cara kematian (natural versus unnatural atau tidak dapat diterangkan). ${ }^{9}$ Sebuah tugas penting dari dokter yang melakukan pemeriksaan luar postmortem adalah mengetahui riwayat medik pasien. Pada prinsipnya dokter yang merawat juga harus diikutsertakan pada pemeriksaan postmortem. Pada banyak kasus kematian berkisar $60-70 \%$, informasi dari dokter yang merawat sangat membantu menerangkan penyakit dasar pasien dan penyebab kematian berdasarkan riwayat medik pasien dan hal-hal yang berhubungan dengan waktu kematian. ${ }^{9}$ Masalah terjadi apabila kematian terjadi secara mendadak dan tidak terduga dan bila hanya dengan pemeriksaan luar postmortem maka penyebab kematian tidak dapat ditentukan. ${ }^{6,9}$ Melalui evaluasi kondisi penyakit yang berpotensi menjadi penyebab kematian telah membantu mengarahkan ahli kedokteran forensik menentukan klasifikasi temuan postmortem. Jika sebab kematian tidak dapat ditegakkan dari pemeriksaan luar postmortem atau dari wawancara dokter yang merawat, hal ini harus dicatat dan cara kematian tidak dapat diterangkan. ${ }^{9}$

Penentuan sebab kematian berdasarkan pemeriksaan luar postmortem dapat ditentukan dengan cara mengumpulkan data medik bahwa korban mempunyai riwayat penyakit kardiovaskuler. Data diambil dari wawancara (autopsi verbal) dengan keluarga korban, menelusuri rekam medik dan atau wawancara dengan dokter yang pernah merawat korban sebelumnya. Penentuan sebab kematian diperkuat juga dengan adanya saksi yang melihat bahwa korban mengalami serangan penyakit mendadak yang dengan sendirinya menyingkirkan kemungkinan adanya trauma dan keracunan. ${ }^{6}$ Penentuan sebab kematian pada kasus seperti ini berdasarkan kondisi klinis korban (sebab kematian klinis). ${ }^{6,10}$ Langkah-langkah penentuan sebab kematian berdasarkan pemeriksaan postmortem dengan mencari tanda-tanda klinis penyakit kardiovaskuler melalui pemeriksaan luar postmortem diantaranya::6,9,12,13,14 
a. Kakeksia kardiak akibat gagal jantung

b. Clubbing finger (jari gada) akibat penyakit jantung kongenital atau endokarditis infektif

c. Makulapapular erimatosa akibat endokarditis infektif

d. Perdarahan splinter dan lesi vaskulitik pada jari tangan akibat endokarditis infektif

e. Xantomata tendon akibat hiperlipidemia

f. Ikterus pada sklera akibat gagal jantung kongestif

g. Xantelasma berupa warna kuning sekitar mata akibat hiperlipidemia

h. Pitting edema berat pada tungkai akibat gagal jantung kongestif dan perikarditis konstriktif

i. Sianotik pada beberapa kelainan jantung

j. $\quad$ Beberapa tanda lain yang spesifik

\section{AUTOPSI FORENSIK}

Apabila penyebab kematian melalui pemeriksaan luar postmortem tidak dapat ditentukan maka perlu dilakukan autopsi baik autopsi forensik maupun klinis. ${ }^{6,9,12,14}$ Namun perlu diperhatikan bahwa autopsi juga belum dapat dikatakan menentukan sebab kematian kausalitas ${ }^{14}$, pada temuan adanya penyempitan koroner mungkin sesuai dengan sebab kematian epidemiologis namun belum cukup dijadikan bukti kausal perlu pemeriksaan lain (histologi, patologi, toksikologi, biokimia dan biologi molekuler) $)^{6,12,14}$ yang membuktikan bahwa penyempitan koroner mengakibatkan aliran darah ke otot jantung berkurang sehingga mengakibatkan infark iskemik. ${ }^{14}$

Pemeriksaan dalam atas jenazah disebut sebagai autopsi. Autopsi atau seksi, nekropsi, obduksi atau pemeriksaan internal jenazah ini harus dilakukan pada suatu tempat yang penerangannya baik. ${ }^{1}$ Pada saat akan melakukan autopsi, sebaiknya dokter melakukan wawancara dengan keluarga jenazah (alloanamnesis). Hal ini bertujuan untuk mencari data mengenai riwayat penyakit, trauma atau gejala-gejala yang dikeluhkan atau diketahui diderita almarhum menjelang kematiannya, historia morbi juga menyangkut penyakit yang diderita jenazah sebelumnya baik yang baru maupun yang lama termasuknya juga riwayat pengobatan dan perawatan. ${ }^{15}$ Dokter akan sangat terbantu dengan pengalaman serta pengetahuan klinisnya untuk menentukan penyebab kematian paska autopsi, berdasarkan pengetahuan dan pengalaman serta keterangan tersebut, dokter dapat lebih yakin untuk mencari keadaan tertentu sebagai penyebab kematian pasien tersebut. ${ }^{16}$ 
Keputusan yang diambil dokter ketika melakukan autopsi merupakan titik awal untuk pencarian penyebab kematian yang lebih pasti berdasarkan hasil-hasil temuan pada pemeriksaan jenazah. Apabila dokter menemukan beberapa kelainan yang mengarah kepada penyebab kematian, maka dokter dapat menentukan kelainan mana yang merupakan penyebab kematian utama, serta menentukan penyebab kematian sekunder yang turut mempunyai andil dalam terjadinya kematian tersebut. ${ }^{15,16,17}$ Menurut World Health Organization (WHO), penyebab kematian adalah semua kondisi penyakit atau cedera yang mengakibatkan atau berkontribusi dan pada akhirnya menimbulkan kematian atau penyebab luar kecelakaan atau kekerasan yang mengakibatkan cedera sehingga berujung pada kematian. ${ }^{18}$

\section{PEMERIKSAAN PENUNJANG}

Apabila autopsi yang dilakukan dokter ditambah dengan pemeriksaan histologi, patologi, toksikologi, biokimia dan biologi molekuler maka hasilnya akan lebih baik, ${ }^{6,12}$ dan dari sudut medikolegal lebih dapat dipertanggungjawabkan sebagai sebab kematian kausalitas. ${ }^{14}$ Pemeriksaan histologi standar yang dilakukan untuk melihat kelainan otot jantung adalah dengan pewarnaan H\&E dari sampel dinding jantung kiri, atria kanan dan septum ventrikular, dan untuk jaringan ikat dilakukan dengan pewarnaan von Gieson, trichome atau Sirius red. ${ }^{6}$ Pada saat dilakukan autopsi dan pemeriksaan histologi-patologi dapat ditemukan secara detil kelainan arteri koronaria terutama pada pasien muda setelah berkonsultasi dengan patolog cardiologi. Namun tidak semua penyebab kematian mendadak kardiovaskuler (KMK) dapat ditentukan dengan autopsi, hal ini disebut sebagai "autopsi negatif" yang dapat disebabkan : (1) autopsi gagal menemukan penyebab kematian, (2) tidak ada etiologi dari kardiovaskuler. ${ }^{12}$ Kombinasi pemeriksaan morfologi, histokimia dan biokimia dapat mendeteksi kelainan miokardium secara lebih akurat. Studi yang dilakukan di Kopenhagen dan Granada berhasil menemukan kelainan pada beberapa sisi otot jantung dengan pemeriksaan Nitro Blue Tetrazolium, cardiac cross section, light microscopy dan fluorosensi. ${ }^{6}$ Penyelidikan molekuler dapat mendeteksi mutasi gen dari struktur dan non struktur genetik dari penyakit jantung, mutasi patogen dari sindrom long $Q T$ dan cathecolaminergic polymorphic ventricular tachycardia telah dilaporkan pada kematian mendadak usia muda. ${ }^{6}$

Secara skematis penentuan sebab kematian berdasarkan pemeriksaan postmortem terangkum dalam bagan $2:^{6,9,12,13,14}$ 


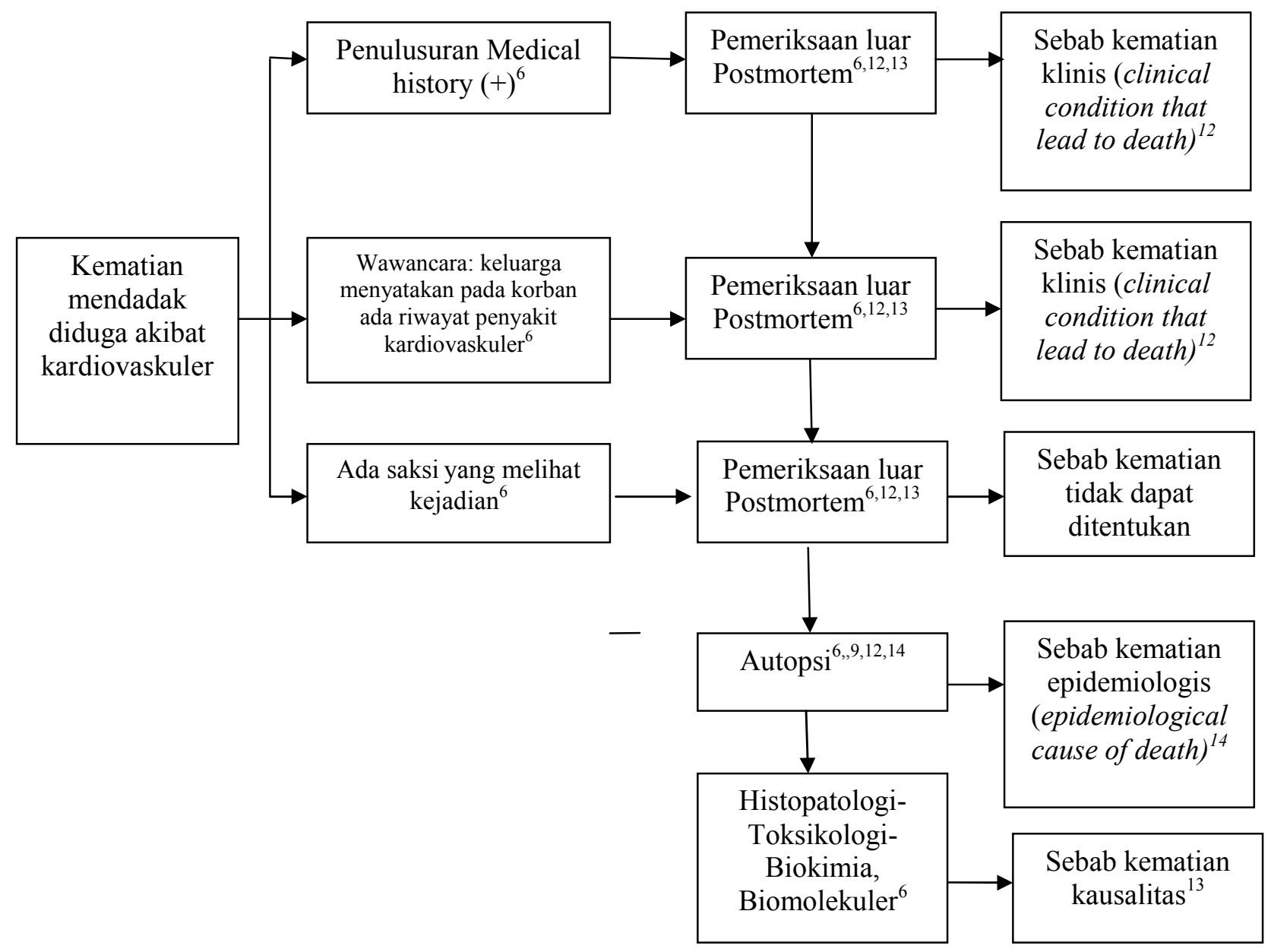

Bagan 2. Skema penentuan sebab kematian pada kematian mendadak kardiovaskuler $6,9,12,13,14$

\section{VISUM ET REPERTUM}

Dalam menjalankan tugas sehari-hari, seorang dokter tidak hanya membuat diagnosa medik namun juga membuat surat keterangan medik, dokter mempunyai kewajiban melakukan pemeriksaan medik forensik terhadap korban hidup maupun korban meninggal untuk tujuan membantu penegakan hukum melalui pembuatan visum et repertum. ${ }^{19}$ Pemeriksaan forensik dilakukan terhadap seseorang yang dikirim polisi (penyidik) karena diduga sebagai korban tindak pidana, baik dalam peristiwa kecelakaan lalu lintas, kecelakaan kerja, penganiayaan, pembunuhan, perkosaan, maupun korban meninggal yang pada pemeriksaan pertama polisi, terdapat kecurigaan akan memungkinkan adanya tindak pidana. ${ }^{20}$ 
Visum et Repertum adalah laporan tertulis yang dibuat dokter berdasarkan sumpah/janji yang diucapkan pada waktu menerima jabatan dokter, memuat berita tentang segala hal yang dilihat dan ditemukan pada barang bukti berupa tubuh manusia/benda yang berasal dari tubuh manusia yang diperiksa sesuai pengetahuan dengan sebaik-baiknya atas permintaan penyidik untuk kepentingan peradilan. ${ }^{1,19}$ Pada korban luka perlu penjelasan tentang jenis kekerasan, hubungan sebab akibat dari kelainan, derajat luka, bila korban dirawat berapa lama korban dirawat dan bagaimana harapan kesembuhannya. ${ }^{20}$ Pada korban meninggal harus dijelaskan sebab dan mekanisme kematian. ${ }^{1}$

Dalam hal penentuan sebab kematian pada visum et repertum lebih ditekankan pada temuan postmortem, mekanisme kematian dan cara kematian seperti contoh redaksional berikut ini: Telah diperiksa sesosok jenazah pria, panjang badan $165 \mathrm{~cm}$, perawakan kurus, warna kulit sawo matang, warna rambut hitam pendek dan lurus. Hasil pemeriksaan luar ditemukan wajah tampak pucat, kelopak mata pucat terdapat warna kebiruan pada bibir dan ujung jari tangan, korban tampak kaku pada persendian lengan dan kaki. Hasil pemeriksaaan dalam dijumpai jantung tampak membesar, dan terlihat lebih gelap atau pucat kehitaman, pada otot jantung tampak bercak-bercak keputihan. Dari hasil pemeriksaan luar dan dalam dapat disimpulkan bahwa kematian disebabkan oleh matinya otot jantung (infark miokard) sebagai akibat penyakit jantung yang diderita sebelumnya.

\section{KESIMPULAN}

Penyebab kematian secara umum bisa disebabkan oleh kegagalan fungsi inervasi, sirkulasi dan respirasi, yang ketiganya merupakan pilar utama kehidupan. Dalam hal penulisan surat Visum et Repertum, penyebab kematian disimpulkan dari temuan postmortem, misalnya dijumpai tanda-tanda perdarahan, mati lemas (asfiksia) dan penyakit-penyakit tertentu. Kemampuan dokter dalam mengungkap tanda-tanda klinis juga sangat penting karena kesimpulan visum et repertum terkadang harus diambil dari diagnosis klinis misalnya pada kasus kematian mendadak kardiovaskuler dengan hanya dilakukan pemeriksaan luar postmortem. Penentuan sebab kematian dapat dilakukan dengan berbagai cara yang masing-masing mempunyai karakteristik tersendiri. Apabila penentuan sebab kematian dengan pemeriksaan luar postmortem maka disebut sebab kematian klinis, apabila dilakukan autopsi disebut sebab kematian epidemiologis dan jika ditambahkan pemeriksaan penunjang disebut sebab kematian 
kausalitas. Dari sudut pembuktian medikolegal masing-masing sebab kematian mempunyai kasta yang berbeda yang tentu saja pemeriksaan lengkap mulai dari pemeriksaan luar postmortem, autopsi dan pemeriksaan penunjang berada pada kasta tertinggi.

\section{REFERENSI}

1. Amir A. Rangkaian Ilmu kedokteran Forensik. Medan. Bagian Ilmu Kedokteran Forensik dan Medikolegal. Fakultas Kedokteran Sumatera Utara. 2009.

2. Hanafiah J. Euthanasia. Dalam Etika Kedokteran dan Ajaran Islam. Penerbit Pustaka Bangsa Press. 2008; 160-66.

3. Samil RS. Euthanasia. Dalam Etika Kedokteran Indonesia. Edisi 2. Yayasan Bina Pustaka Sarwono Prawirohardjo. Jakarta, 2001:92-9.

4. Rorora JD, Tomuka D, Siwu J. Temuan otopsi pada kematian mendadak akibat penyakit jantung di BLU RSU Prof.DR. R.D.Kandou Manado periode 2007-2011. Jurnal eClinic (eCI).2014;2.

5. Singh S. Kematian Mendadak. Kedokteran forensik FK USU. Medan. 2013. Available at: http://repository.usu.ac.id/bitstream/123456789/38686/5/Chapter\%20I.pdf.(dikutip12 Nopember 2018).

6. Yang KM, Lee S., Kim YS, Seo JS, Lee YS, Seo JW. Guideline for forensic assesment of natural unexpected cardiovascular death. Basic and applied Pathology 2008; 1: 155-63.

7. Bhaskara, DS, Mallo, JF, Tomuka D. Hasil autopsy sebab kematian mendadak tak terduga di bagian forensik BLU RSUP. Prof.DR.R.D. Kandou Manado tahun 2010-2012. Bagian Ilmu Forensik Fakultas Kedokteran Universitas Sam Ratulagi Manado. 2012.

8. Kementerian Kesehatan Republik Indonesia. Kematian mendadak. Available at: http://www.depkes.go.id/article/v iew/201410080002/lingkungan- sehat-jantung-sehat.html. [dikutip tanggal 12 Nopember 2018].

9. Madea B and Rothschild M. The Postmortem External Examination, Determination of the Cause and Manner of Death. Dtsch Arztebl Int 2010; 107(33): 575-88.

10. Houck MM. External Postmortem Examination. In: Forensic Pathology. London: Shara Teney; 2017. p. 73-81.

11. World Health Organization. Medical Records Manual: A Guide for Developing Countries. Geneva; 2002.

12. Wilhelm M, Bolliger SA, Barstch C, Folkstuen S, Grani C, Martos V, et al. Sudden death in Forensic Medicine- Swiss Recommendations for a multidisciplinary Approach. Swiss Med Wikly. 2015; 145: w14129: 1-6.

13. Talley NJ, O'Connor S. Pemeriksaan Klinis-Pedoman Diagnosis Fisik. Alih bahasa Wendra Ali. Binarupa Aksasa. Jakarta: 1994:30-102.

14. Sampurna B. Bukti Medis Versus Bukti Hukum. Indonesian Journal of Legal and Forensic Science 2012: 2(2): 27-30.

15. Dahlan, S. 2004. Otopsi. Dalam Ilmu Kedokteran Forensik: Pedoman Bagi Dokter dan Penegak Hukum. Semarang: Badan Penerbit Universitas Diponegoro.

16. Anonymous. 2018. Pemeriksaan Jenazah. (Online). (Available at http://www. scribd.com/doc/81814383/pemeriksaan-jenazah. Diakses 14 November 2018).

17. Muhlisin, A. 2018. Autopsi. (Online). (Available at http://mediskus.com/penyakit/autopsiotopsi.html. Diakses 14 November 2018). 
18. World Health Organization. International Statistical Classification of Diseases and Related Health Problems. Ganeva; 2005.

19. Afandi D. Visum et Repertum Perlukaan: Aspek Medikolegal dan Penentuan Derajat Luka. Maj.Kedokt Indon. Vol 60. No.4; 2010: 188-95.

20. Susanti R. Paradigma Baru Peran Dokter dalam Pelayanan Kedokteran Forensik. Majalah Kedokteran andalas. Vol.36. No.2; 2012:145-52. 